\title{
Evaluation of the Water Quality of Tidal Creeks of Pontal do Paraná, Paraná, Brazil
}

\author{
Adriana Siqueira $^{1 *}$, Mirna Januária Leal Godinho ${ }^{2}$, Hedda Elisabeth Kolm ${ }^{1}$ and Eunice da \\ Costa Machado ${ }^{1}$ \\ ${ }^{l}$ Centro de Estudos do Mar; Universidade Federal do Paraná; C. P.: 50.002; 83.255-000; Pontal do Sul - PR - \\ Brasil. ${ }^{2}$ Departamento de Ecologia e Biologia Evolutiva; Universidade Federal de São Carlos; Via Washington \\ Luís Km 235; C.P.: 676; 13565-905; São Carlos - SP - Brasil.
}

\begin{abstract}
The aim of this wat was to evaluate the water quality in four tidal creeks of Paraná, Brazil, with different anthropic influences. Samples were collected every three months. Temperature, salinity, pH, alkalinity, total $\mathrm{CO}_{2}$, dissolved $\mathrm{O}_{2}$, nitrite, nitrate, $\mathrm{N}$-ammoniacal, phosphate, silicate, particulate suspended matter, humic matter, total chlorophyll, total and fecal coliform bacteria of surface water were measured in each sample and compared. For all the stations water temperature was lower in winter, but ranged within typically subtropical values. Salinity (7 - 25) and $\mathrm{pH}(7.08$ - 7.91) were higher in Perequê tidal creek indicating that only this tidal creek was strongly influenced by the nearby ocean waters. Lower dissolved $\mathrm{O}_{2}$, reaching anoxic levels along with higher phosphate and $\mathrm{N}$ ammoniacal concentrations and higher total $\left(<200-160,000 \mathrm{MPN} 100 \mathrm{ml}^{-1}\right)$ and thermotolerant coliforms $(<200-$ 50,000 MPN $100 \mathrm{ml}^{-1}$ ) in Olho d'Água suggested euthrophication, especially in summer when rainfall was higher and tourism was at its peak. Perequê, Penedo and Barranco Creeks were characterized as meso-and oligotrophic environments.
\end{abstract}

Key words: tidal creek, eutrophication, coast of Paraná.

\section{INTRODUCTION}

The landscape of the Brazilian coastal areas are being altered due to the growth in consequence of the tourist demand, increase of harbor activities, extraction and transport of petroleum along the coast, as well as due to a gradual implementation of aquaculture increasing water pollution and euthrophication.

Controlled release of organic wastes can provoke an increment in the local primary productivity, but its excesses are harmful as it may cause euthrophication of the ecosystems (Bishop, 1985).
Almeida (1984) reposted that the release of sewers in natura besides the harmful effects on water quality and population health, presented a risk to the tourism and to marine natural resources.

Extreme situations in aquatic ecosystems can be represented by alterations in nitrogen and phosphorus concentrations, due to the contribution of organic matter from domestic sewers. These may determine the unbalance in the phytoplanktonic population, because they favor microalgae and cyanobacteria blooms whose toxins constitute a risk to public health. Also, this

*Author for correspondence: a.siqueira2910@ hotmail.com 
may affect the areas for bivalve cultivation for human consumption (José, 1996).

Rivers and tidal creeks of coastal environments are important because they serve as the liaison between the terrestrial and marine environment, accomplishing the transport of fresh water, organic matter, nutrients and contaminant from the continent to the sea. Tidal creeks are meandrous water courses, characteristic of littoral plains of great estuarine complexes. In these water courses, the contribution of fresh water comes from the rainfall and, mainly, from the surfacing of shallow water (Marone et al., 1997) and in the areas close to cities and towns, of domestic and/or industrial sewers. This way, tidal creeks, differs from the rivers because they do not have a nascent. The low inclination of littoral plain allows intrusion of brackish waters, originating from the estuaries (Lana et al., 1997), and saline waters from the continental platform constantly modifying the salinity values with the change of the tides.

The objective of the present study was to evaluate the water quality in relation to the trophic status of four tidal creeks located in Pontal do Paraná (PR, Brazil) that have bean under different anthropic influences, through the study of spacial and temporal dynamics of physical, chemical and biological variables.

\section{MATERIAL AND METHODS}

\section{Studied area}

Paraná coast is located in the south of Brazil (Fig. $1 \mathrm{~A}$ and $\mathrm{B}$ ) and extends from the Ararapira village $\left(25^{\circ} 12^{\prime} 44^{\prime \prime} \mathrm{S}-48^{\circ} 01^{\prime} 15^{\prime \prime} \mathrm{W}\right)$ to the mouth of Sai-

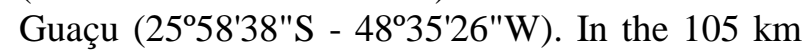
of oceanic coast, a great contrast is observed among the areas of the south coast, quickly urbanized in the recent decades in function of the tourist flow during the summer and preservation areas in the north (Environmental Protection Area of Guaraqueçaba and the National Park of Superaguí) (Soares et al., 1997).

Pontal do Paraná is inserted in the coastal plain of Paraná State (Fig. 1A). Its beaches extend from the DNOS Channel (Departamento Nacional de Obras e Saneamento - artificial drainage channel), in the outlet of the Paranaguá Bay to Monções balneary, south limit of the municipal district (Fig. 1B and C). In the present work physical, chemical and biological variables of the tidal creeks Perequê (G1), Penedo (G2), Barranco (G3) and Olho
d'Água (G4), all located in Pontal do Paraná, were investigated.

The Perequê tidal creek, $2.6 \mathrm{~km}$ long, is typically meandrous with outlet in the DNOS Channel, close to the entrance of Paranaguá Bay. Part of its extension divides Pontal do Sul in two sections (Kolm and Andretta, 2003). Along its margins, banks of Spartina alterniflora and mangroves are found. In the highest and driest parts of the tidal creeks Hibiscus tiliaceus and restinga vegetation occurs. Close to the outlet marinas of small and medium size are established. The most internal station, that is, the nearest to the origin of the drainage zone (St. 1) is located close to the main street of Pontal do Sul. In its margins there are impacted mangroves and commercial and residential houses. The median station (St. 2) is located in a curve of the tidal creek with typical restinga thickets on its margins. The external station (St. 3), located close to the outlet, is placed in a marinas' area with accentuate traffic of fishing and tourism boats (Fig. 1D).

Penedo tidal creek, with $3 \mathrm{~km}$ long ends in the section of high energy of Paranaguá Bay, is environmentally preserved. In the external section, swamp vegetation dominates. In the internal, restinga thickets prevails. The internal station (St. 4) is located amid a thicket. The median station (St. 5) has restinga arboreal vegetation little impacted in its margins. Close to the outlet, on the beach, in an area with mangroves of small size, the external station is located (St. 6) (Fig. 1E).

Barranco tidal creek, with approximately $2.6 \mathrm{~km}$ long, does not receive served waters directly from the town located on its margins, which, according to the inhabitants' information, possesses septic tanks system. Restinga vegetation prevails along its margins, with typical dunes vegetation in the outlet proximities of the exposed beach. The internal station (St. 7) is located amid the arboreal vegetation. Lemna sp. and grass dominates the water surface. Station 8 (St. 8) is located close to a bridge in the highway PR-412 that interconnect the balnearies of the municipal district. It is marginated by restinga vegetation, mainly grass.

On the surface of the water, there are aquatic macrophytes, mainly Myriophyllum aquaticum. The most external station is located close to the outlet (Est. 9) and it is marginated by typical vegetation of restinga and dunes. Between the median and external stations is located the Barranco balneary (Fig. 1F). 
Olho d'Água tidal creek, $2.7 \mathrm{~km}$ long, is located in urbanized areas of the Ipanema balneary. A series of artificial channels run into this tidal creek. According to information of the City Hall of Pontal do Paraná this tidal creek receives waters of the Peri River located upstream and receiver of the leachates originating from of the third pond of the sanitary landfill of the region. The internal (St. 10) and median (St. 11) stations differ from each other in relations to the vegetation that covers its waters. While the first is hidden by the grass, the second is by Pistia stratiotes. The most external station (St. 12), located near the outlet, has characteristics similar to the median station (Fig. 1G).

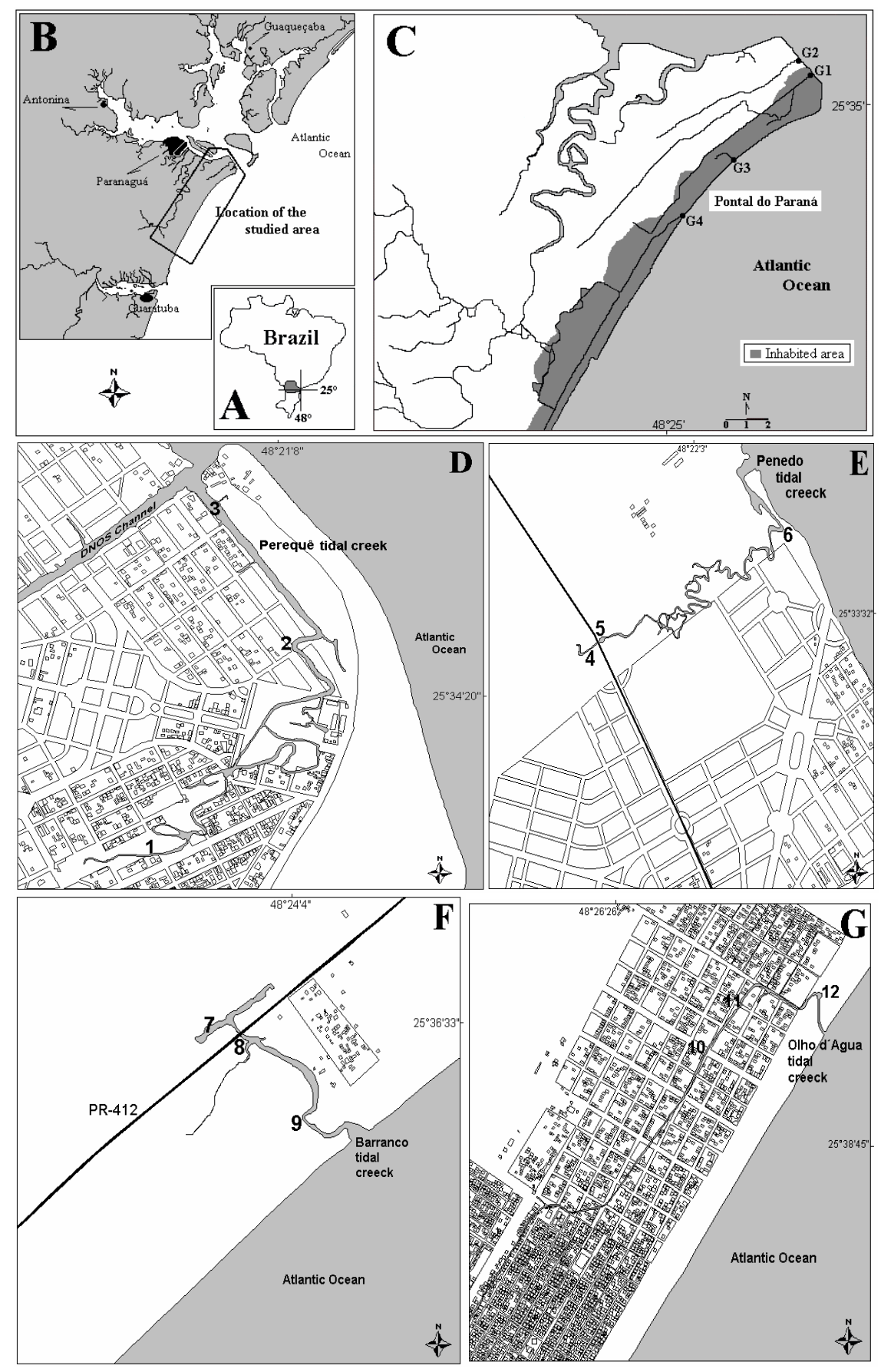

Figure 1 - A) Map of Brazil with location of Paraná coast; B) Map of Paraná coast with location of Pontal of Paraná; C) Location of the studied areas; D) Perequê tidal creek (G1); E) Penedo tidal creek (G2); F) Barranco tidal creek (G3) and G) Olho d'Água tidal creek (G4). The four maps of the tidal creeks show the location of the sampling stations. 


\section{Sampling design and analyses}

Samplings were accomplished in low-water of spring tide, in four tidal creeks of Pontal do Paraná. Surface waters were collected from three points in each tidal creek: 1, 2 and 3 - Perequê; 4, 5 and 6 - Penedo; 7, 8 and 9 - Barranco and 10, 11 and 12 - Olho d'Água. Due to the long distance between one tidal creek to the other, the samplings were done on consecutive days. The samples were obtained every three months: in autumn (April), winter (July) and spring (October) of 2003 and summer (January) and autumn (April) of 2004.

The water temperature was determined in situ with a mercury thermometer $\left(1 / 100{ }^{\circ} \mathrm{C}\right)$, salinity with refratometer (ATAGO, S/MILL), $\mathrm{pH}$ with $\mathrm{pH}$ meter (HANNA HI 8424) and the alkalinity by Gran titration (Carmouze, 1994). Total carbon dioxide $\left(\mathrm{CO}_{2}\right)$ was calculated from temperature data, salinity, pH and alkalinity (Carmouze, 1994) and dissolved oxygen (DO) was analyzed according to the Winkler method (Grasshoff et al., 1983). For the other analyses, water samples were filtered through GF/F (Whatman) filters after each sampling and stored at $-18^{\circ} \mathrm{C}$. Analyses of dissolved inorganic nitrogen $(\mathrm{DIN}=$ nitrito + nitrate $+\mathrm{N}$-ammoniacal), phosphate and silicate were carried out according to Grasshoff et al. (1983). The particulate suspended matter (PSM) was determined by gravimetric method (Strickland and Parsons, 1972). The concentration of humic substances (HS) was determined in spectrophotometer (SHIMADZU UV - 1601 PC) light absorption $\left(\lambda_{360} \mathrm{~nm}\right)$ according to the methodology described by Kirk (1994). For total chlorophyll analysis, the samples were pré-filtered in a net with $0.5 \mathrm{~mm}$ of mesh size, before the filtration. Total chlorophyll was extracted with acetone $(90 \% \mathrm{v} / \mathrm{v})$ and analyzed fluorimetrically (TURNER AU-10) according to Parsons et al. (1984). Total and thermotolerant coliforms were determined by the method of the multiple tubes (Greenberg et al., 1985).

Statistical evaluation of the results was accomplished through the Analysis of Variance (ANOVA), using the program STATISTICA 6.0 (StatSoft, Inc. 1999). When temporal and/or spacial variation was significant, the results were represented in the form of graphs with the values of $\mathrm{F}$ and $\mathrm{p}$ inserted. The level of significance was $95 \%$.

\section{RESULTS}

There was a temperature gradient, with values significantly lower in the winter, intermediate in the autumn and spring and high in the summer along the period studied (Fig. 2A). In relation to the salinity, significantly high values were registered in Perequê's tidal creek (Fig. 2B). In the other tidal creeks, low salinities were detected (between 2 and 15\%o) mainly in the external stations. Similar results were observed for higher $\mathrm{pH}$ values in Perequê tidal creek (Fig. 2C).

However, unlike the salinity that did not vary significantly along the year, the $\mathrm{pH}$ was higher in the spring and autumn of 2004 (Fig. 2D). While the $\mathrm{pH}$ values of Perequê and Olho d'Água tidal creeks were similar at all the stations, in Penedo and Barranco a gradient with higher values in the external stations was observed. In spite of the smallest values of total $\mathrm{CO}_{2}$ calculated in Perequê's three stations, little temporal variability was observed in the most part of the period and stations. However, extremely high values found in January of 2004 , in the internal $(33,700 \%)$ and median $(69,250 \%)$ stations of Penedo tidal creek, contributed to the significant variation in the summer (Fig 2E). Figure 2F shows a clear gradient in the concentration of DO, with higher values in the external stations of the tidal creeks Perequê, Penedo and Barranco. The same was not observed in the tidal creek Olho d'Água, where DO values were extremely low, up to anoxic level in all stations in the winter. It was worth to comment that no DO value surpassed the $80 \%$ of saturation. In relation to the concentrations of dissolved inorganic nitrogenous nutrients, temporal and spacial variation of nitrite and nitrate as for the Nammoniacal was observed. Nitrite concentrations were significantly lower in Barranco tidal creek (Fig. 3A) mainly during the autumn of 2003 (0.03 $\mu \mathrm{M})$. However, in most of the stations, low concentrations of this nutrient were registered in the autumn of 2003, increasing gradually until summer and again lowering in the autumn of 2004 (Fig. 3B). The median Barranco tidal creek stations and the external of Perequê tidal creek were exceptions where there was no reduction of this nutrient in autumn of 2004. The maximum values $(1.80 \mu \mathrm{M})$ were registered in the spring in Perequê's internal station. 

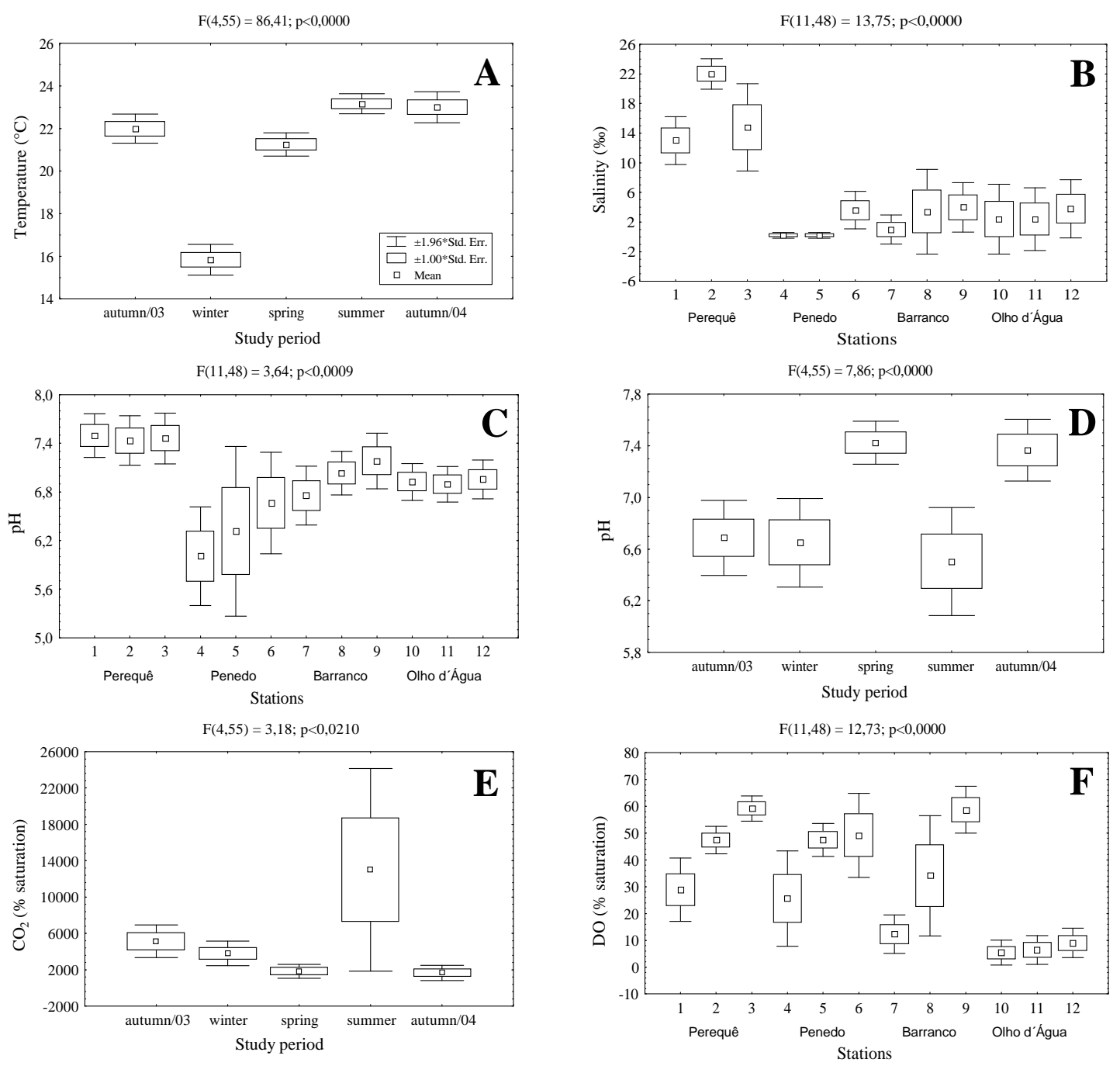

Figure 2 - Spatial and temporal variation with average and standard deviation: A) Temperature during the studied period; B) Salinity in the twelve studied stations; C) $\mathrm{pH}$ in the twelve studied stations; D) $\mathrm{pH}$ during the studied period; E) Total $\mathrm{CO}_{2}$ during the studied period and F) Dissolved oxygen in the twelve studied stations.

The largest concentrations of nitrate, with a maximum of $7.95 \mu \mathrm{M}$ in the winter, were found in Perequê's internal station (Fig. 3C). In Penedo tidal creek, the values were intermediary, varying between $0.14 \mu \mathrm{M}$ in the autumn of 2003 and 3.76 $\mu \mathrm{M}$ in the spring, both in the median station. In Barranco and Olho d'Água, the lowest concentration of this nutrient was observed in the external station of Olho d'Água. The concentrations of nitrate were higher in the winter and in the spring (Fig. 3D).

While nitrite and nitrate were higher in Perequê tidal creek, the largest concentrations of $\mathrm{N}$ - ammoniacal were found in Olho d'Água tidal creek, with a maximum of $75.33 \mu \mathrm{M}$, in the internal station in the summer and autumn of 2004 and in the external station in the summer. Intermediary values, varying among $62.90 \mu \mathrm{M}$ in the internal station in the summer and $2.58 \mu \mathrm{M}$ in the external station in the winter were registered in Perequê tidal creek, followed by Penedo (Fig. 3E). In Perequê tidal creek, an increase of this nutrient was observed in the spring and in the summer and in Olho d'Água tidal creek the largest concentrations occurred in spring, summer and autumn of 2004 (Fig. 3F). 

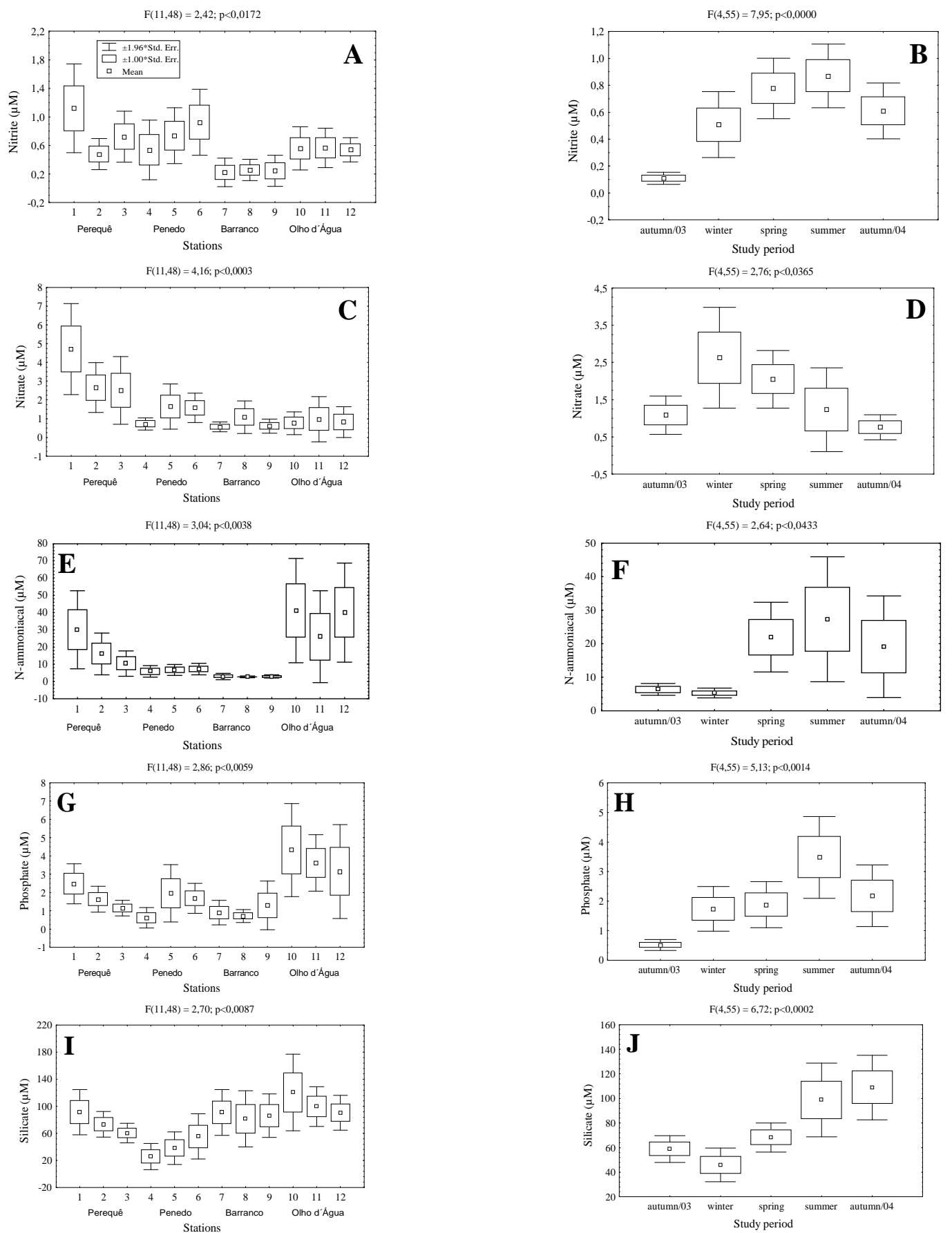

Figure 3 - Spatial and temporal variation with average and standard deviation: A) Nitrite in the twelve studied stations; B) Nitrite during the studied period; C) Nitrate in the twelve studied stations; D) Nitrate during the studied period; E) N-ammoniacal in the twelve studied stations; F) N-ammoniacal during the studied period; G) Phosphate in the twelve studied stations; H) Phosphate during the studied period; I) Silicate in the twelve studied stations and J) Silicate during the studied period.

The variability of phosphate concentration was also significant, as in space and time (Fig. $3 \mathrm{G}$ and $\mathrm{H})$. Its largest concentrations, with a maximum of
$8.55 \mu \mathrm{M}$ in the internal station in summer, were registered in the stations of Olho d'Água. 
Intermediary concentrations were registered in the Perequê and Penedo, and lower in Barranco. Along the studied period, a gradual increase between the autumn of 2003 and summer and a reduction in the autumn of 2004 was observed in most stations. The median stations of Penedo and Olho d'Água, presented the largest values in the autumn of 2004.

The largest silicate concentrations, with maximum of $208.11 \mu \mathrm{M}$ in the internal station in the autumn of 2004, was observed in Olho d'Água tidal creek, followed by Barranco and Perequê, and the smallest $(8.11 \mu \mathrm{M})$ in the internal station during the winter in Penedo (Fig. 3I). However, while in Perequê and Olho d'Água tidal, creeks presented a decrease of this nutrient from the internal section to the outlet, in Penedo the inverse was observed. In Barranco, the values were similar at all the stations. In relation to the temporal variability, in Olho d'Água, Perequê and Barranco the concentrations were larger in the summer and autumn of 2004 whereas in Penedo they were larger in the autumn of 2003 and in the spring. Such results confirmed the significantly larger variability in summer and autumn of 2004 shown in figure $3 \mathrm{~J}$.

The largest concentrations of PSM, with a maximum of $76.87 \mathrm{mg} .1^{-1}$ registered in the median station in winter, were found in Perequê tidal creek and the smallest, with a minimum of $0.73 \mathrm{mg}^{-1}{ }^{-1}$ in the median station in the winter in Penedo (Fig. 4A).
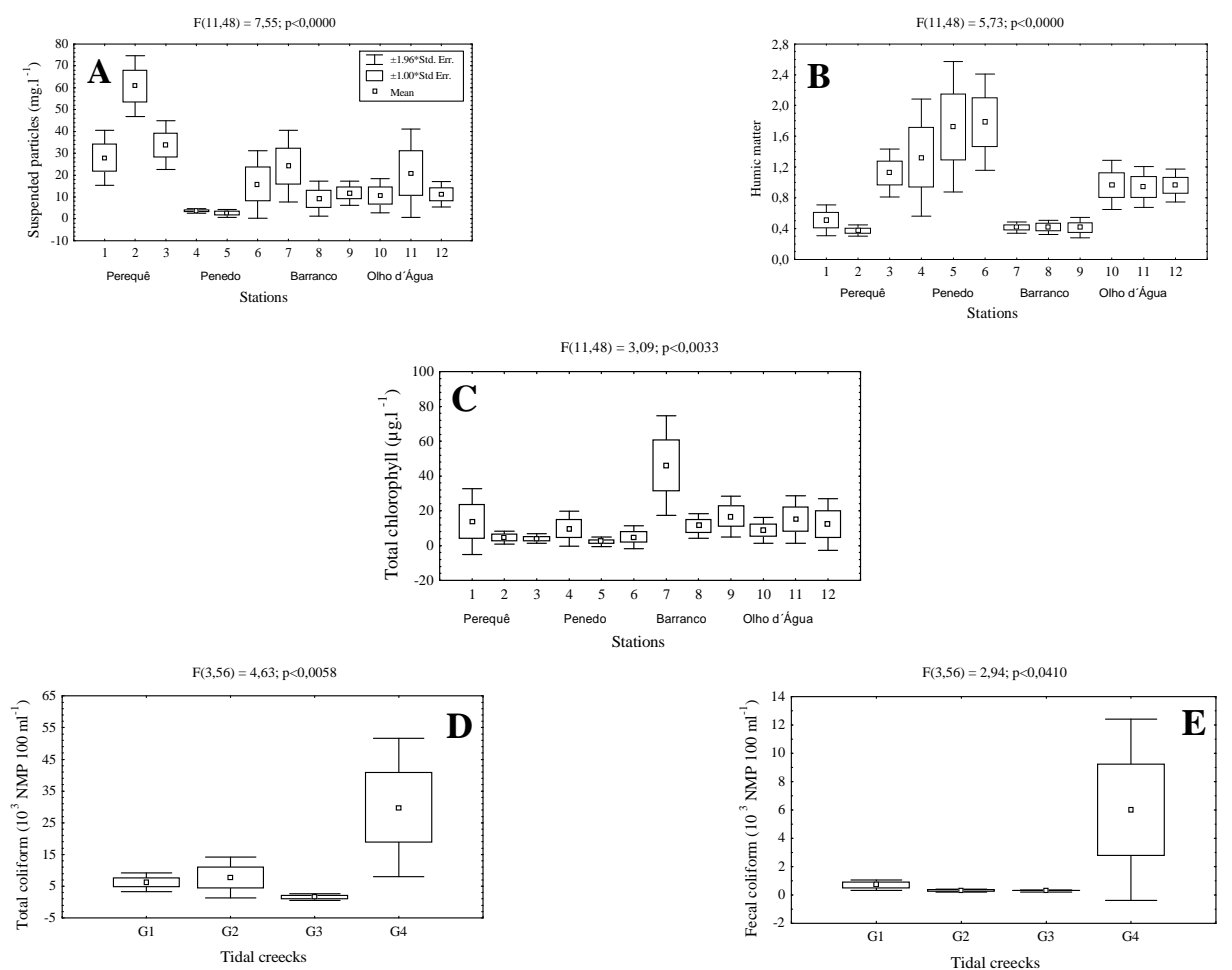

Figure 4 - Spatial variation with average and standard deviation: A) Particulate material in suspension B) Humic substances and C) Total chlorophyll, in the twelve studied stations; D) Total coliforms and E) Thermotolerant coliforms, in the four studied tidal creeks.

The amounts of HS in the water varied considerably from a tidal creek to another. While in Penedo and in the external station of Perequê, the largest values were registered, in Barranco the smallest was observed (Fig. 4B).

There was little variability in total chlorophyll in most of the studied stations. However, higher values were observed in the internal stations of
Perequê, Penedo and Barranco tidal creeks. Of these, only the ones of Barranco's internal station, with a maximum of $90.03 \mu \mathrm{g} . \mathrm{l}^{-1}$ in the summer, presented significant variability (Fig. 4C).

Total and thermotolerant coliforms were higher in Olho d'Água tidal creek (Fig. 4D and E), mainly during the summer, when they reached a maximum of 160,000 and 50,000 MPN $100 \mathrm{ml}-1$ 
in the internal station respectively. High values of total coliforms could still be observed in the median stations of Penedo and Perequê tidal creek during the summer. In relation to thermotolerant coliforms, larger values were observed in Perequê than in Barranco and Penedo tidal creeks.

\section{DISCUSSION}

The climate of Pontal do Paraná region has been defined, as tropical of transition, with hot and rainy summers (Maack, 1981). These characteristics are reflected in the low temperatures of the water observed during the winter in all the stations of the studied tidal creeks. However, it is important to observe that temperature increases, registered in Olho d'Água tidal creek, in the autumn and winter of 2003 were related to the sampling period, around midday.

The significant intrusion of saline waters from the continental shelf was only observed in the Perequê tidal creek. Kolm and Andretta (2003) studied the salinity of this tidal creek and observed high marine influence along significant part of its extension. Part of the Perequê's bed was artificially altered in the past and ended in the DNOS channel dredged artificially in the 1950's decade. Close to the outlet of this channel lateral promontories were installed with the intension of reducing shoaling. All these characteristics facilitate the entrance of saline waters in this tidal creek and consequent $\mathrm{pH}$ increase. In the other tidal creeks the influence of marine waters in the periods of low tide was reduced. The results showed that the intrusion of saline water in the tidal creeks varies from one to another and depended mainly from the profile configuration of the adjacent beach. However, considering that brackish waters are classified as those whose salinity varies between 0.5 and $30 \%$ o (CONAMA, 2005), the waters studied in this research could be considere in such category.

The largest values of PSM were observed mainly in the tidal creek Perequê's median area. In this tidal creek, the largest salinity values were also registered. This suggested that it was influenced directly by the flow and ebbing of the tides and consequent ressuspension of the sediment. Fine sediments could be carried during the tide ebbing to the tidal creeks' bed. This confirmed the observations of Marone et al. (1997) about the entrance of particulate material from the estuary to the tidal creek.
High $\mathrm{pH}$ values were registered in Perequê, Barranco and Olho d'Água tidal creeks. However, the low values observed in Penedo's internal station, seemed to be directly related to the amount of SH. Great part of this tidal creek is located in a thicket with little anthropic alteration, slow water flow and high input of organic matter from the adjacent vegetation. The low amount of rainfall and consequent increase of the residence time of the water, registered in the spring $(29.72 \mathrm{~mm}$ in six days that preceded the sampling day inclusive), and mainly in autumn of $2004(4.32 \mathrm{~mm}$ in six days that preceded the sampling day inclusive) seemed also to corroborate these results.

The values of total $\mathrm{CO}_{2}$ were relatively constant along the studied period for all the stations. However, higher values were observed in Penedo's external stations during the summer. This may be due to the largest rate of decomposition of organic matter favored by the temperature elevation in this period.

Significant DO variations were registered in sampling stations of Penedo, Perequê and Barranco tidal creeks, where a clear gradient, with higher values in the external stations was observed. The largest flow, due to the introduction of water through the water table and consequent introduction of oxygen of the air, seemed to be the decisive factor. Totally different characteristics were found in the tidal creek Olho d'Água, where DO was low in the three stations. These results, accompanied by high concentrations of $\mathrm{N}$ ammoniacal, phosphate, total and thermotolerant coliforms, were related to the low renewal of the water, to the contribution of great amount of organic matter originated, not only from the vegetation (formed mainly of aquatic macrophytas), but also from domestic sewers. Besides, the existence of a film of superficial fat in the internal station, that could hinder the interaction water/air, should be considered. In none of the studied tidal creeks, the DO reached values equal or above $100 \%$ of saturation, frequently found in the waters of Paranaguá Bay (Machado et al., 1997 and Kolm et al., 2002). The levels of DO under $100 \%$ of saturation together with values of super saturated total $\mathrm{CO}_{2}$ suggested that the metabolism of the investigated tidal creeks was predominantly heterothrofic (Carmouze, 1994).

According to Taniguchi (2004), the availability of DO affected nitrate concentration, determining nitrification and denitrification rates. This 
correlation was only observed in Perequê tidal creek, where a reduction of nitrate from the internal to the external station was found. In the others tidal creeks, this nutrient was low, in spite of the variations of DO. However, there were indications that the variability of this nutrient in the tidal creeks could be related to the aquatic vegetation that differs from one to another. This was corroborated by the fact that in the stations and in different months of sampling, the N:P rate was lower than 16 , showing that nitrogen was the potentially limiting element as it usually happens in estuarine and coastal ecosystems (Thom et al., 1994 and Baumgarten et al., 1995). The low nitrite values in relation to the nitrate registered in all the stations confirmed the findigs of Marques' (2003), who reported that among the forms of dissolved inorganic nitrogen, nitrite was difficult to detect in natural waters because of its instability.

Chlorophyll concentration was higher in the internal stations of the tidal creeks Perequê, Penedo and Barranco. However, it should be noted that the high values observed in Barranco's internal station could have been influenced partly by Lemna sp. which have not been retained by the pre-filtration process.

The highest values of total and thermotolerant coliforms were observed in Olho d'Água tidal creek, which were similar to those registered annually in the summer period by the Environmental Institute of Paraná, that find waters not proper for balneability in the proximities of its mouth. The high values of total coliforms and low values of thermotolerant coliforms in Penedo tidal creek confirmed previous observations of Kolm et al. (2002) that the part of the total coliforms were autochthonous. The analyses of total coliforms, accomplished by Higuti et al. (1998) in Penedo tidal creek, showed similar results during the winter and spring. The present work showed that during the summer and autumn of 2003, they were significantly higher, whereas thermotolerant coliforms were more elevated in the summer. These results showed little anthropic influence during the last years, except for the summer time in which the tourism increase. Kolm and Andretta (2003) studied total coliforms and E. coli in two spring-tide in July 1999 in Perequê tidal creek. The average of the values of total coliforms found by the authors was, in the external station, similar to the ones found in this stydy in July 2003. However, in the median station the values of total coliforms were significantly higher in this study. The analysis showed that, in agreement with the Resolution 274 of CONAMA 2000, the water of Olho d'Água tidal creek followed by Perequê was classified as unsatisfactory for balneability.

Brickner et al. (2003) classifed the waters quality from concentrations of chemical and biological variables. Following that, it was concluded that during the studied period, only in the summer Perequê's internal station presented euthrophic characteristic. Similar characteristics were observed in the internal and external stations of Penedo tidal creek in the summer and in the median station in the autumn of 2004. Barranco tidal creek only presented euthrofization characteristics in the internal station in the winter and Olho d'Água presented higher euthrofication characteristics, reaching a maximum in the summer.

\section{ACKNOWLEDGEMENTS}

This work was supported by a grant from $\mathrm{CNPq}$ (Conselho Nacional de Pesquisa e Desenvolvimento Tecnológico). We thank Prof. Dr. Marco Fábio Maia Corrêa for the comments, suggestions and corrections of the first version of the manuscript.

\section{RESUMO}

Foi objetivo da presente pesquisa, avaliar a qualidade da água de quatro gamboas do Paraná, Brasil, que sofrem influências antrópicas distintas. $\mathrm{Em}$ cinco coletas trimestrais, foram obtidas, as seguintes variáveis em águas superficiais: temperatura, salinidade, $\mathrm{pH}$, alcalinidade, dióxido de carbono, oxigênio dissolvido, nitrito, nitrato, Namoniacal, fosfato, silicato, material particulado em suspensão, substâncias húmicas, clorofila total, coliformes totais e coliformes termotolerantes. Os resultados mostraram que a temperatura da água apresentou características tipicamente subtropicais com valores significativamente menores no inverno em todas as estações. A salinidade (7 $25 \%$ ) e o pH $(7,08$ - 7,91) mais elevados, registrados na Gamboa Perequê, indicaram que somente este curso d'água é influenciado pelo mar adjacente. As quantidades baixas de oxigênio dissolvido, chegando a anoxia, altas de fosfato 
$(8,11-208,11 \mu \mathrm{M}), \mathrm{N}$-amoniacal $(0,90-75,33$ $\mu \mathrm{M})$, coliformes totais $(<200-160.000$ NMP 100 $\left.\mathrm{mL}^{-1}\right)$ e coliformes termotolerantes $(<200-50.000$ NMP $100 \mathrm{~mL}^{-1}$ ) observadas na Gamboa Olho d'Água indicam que esta apresenta características típicas de eutrofização, principalmente no verão, época de maior pluviosidade e maior fluxo de turistas na região. As gamboas Perequê, Penedo e Barranco podem ser caracterizadas como gamboas meso-e oligotróficas.

\section{REFERENCES}

Almeida, M. T. (1984), Estudo da poluição orgânica das águas nas imediações da cidade de Rio Grande (RS - Brasil). Atlântica, 7, 15-24.

Baumgarten, M. G. Z.; Niencheski, L. F. H. and Kuroshima, K. N. (1995), Qualidade das águas estuarinas que margeiam o município do Rio Grande (RS, Brasil): nutrientes e detergentes dissolvidos. Atlântica, 17, 17-34.

Bishop, P. L. (1985), Marine pollution and its control. 2 ed., Mc Graw Hill, New York.

Bricker, S. B.; Ferreira, J. G. and Simas, T. (2003), An integrates methodology for assessment of estuarine trophic status. Ecol. Modell, 169, 39-60.

Carmouze, J. P. (1994), O metabolismo dos ecossistemas aquáticos: fundamentos teóricos, métodos de estudo e análises químicas. Ed. Edgard Blücher, São Paulo, Brasil.

Grasshoff, K.; Ehrhardt, M. and Kremling, K. (1983), Methods of Seawater Analysis. 2 ed., Verlag Chemie, Weinheim.

Greenberg, A. E.; Trussell, R. R. and Clesceri, L. S. (1985), Standard Methods. For the examination of water and wastewater. American Public Health Association.

Higuti, I. H.; Macena, I. R.; Masunari, S.; Filho, M. O. B.; Blaskowiski, M. M. M. and do Nascimento, A. J. (1998), Ocurrence of coliforms in water samples of the Perequê and Penedo Rivers in Paraná, Brazil. Braz. Arch. Biol. Technol., 41, 417-422.

Jose, V. F. (1996), Bivalves e a segurança do consumidor. PhD Thesis, USP, São Paulo, Brasil.

Kirk, J. T. O. (1994), Light and photosynthesis in aquatic ecosystems. 2 ed., Cambridge University Press, Cambridge.

Kolm, H. E.; Schoenenberger, M. F. B.; Piemont, M. R.; Souza, P. S. A.; Schnell, E.; Scühl, G.; Mucciatto, M. B. and Mazzuco, R. (2002), Temporal variation of bacteria in superficial waters of Paranaguá and Antonina Bays, Paraná, Brazil. Braz. Arch. Biol. Technol., 45, 27-34.

Kolm, H. E. and Andretta, L. (2003), Bacterioplancton in different tides of the Perequê tidal creeck, Pontal do Sul, Paraná, Brazil. Braz. J. Microbiol., 34, 97103.

Lana, P. C.; Angulo, R. J. and Ribeiro, D. (1997), Estudo do impacto ambiental de uma usina termoelétrica na Baía de Paranaguá e do porto de desembarque, sub-estação e linha de transmissão associados. GETEP/COPEL/CHILGENER/INEPAR, Curitiba, $3^{\circ}$ vol.

Maack, R. (1981), Geografia física do Estado do Paraná. 2 ed., J. Olympio/Curitiba, Secretaria da Cultura e Esporte do Estado do Paraná, Curitiba, Brasil.

Machado, E. C.; Daniel, C. B.; Brandini, N. and Queiroz, R. L. V. (1997), Temporal and spatial dynamics of nutrients and particulate suspended matter in Paranaguá Bay, PR, Brazil. Nerítica, 11, 1534.

Marone, E.; Mantovanelli, A.; Klingenfuss, M. S.; Lautert, L. F. C. and Prata Jr., V. P. (1997), Transporte de água, sal, material particulado em suspensão e calor na Gamboa Perequê num evento de maré de sizígia. Paper presented at VII Congresso latino-americano sobre Ciências do Mar. Santos, São Paulo.

Marques, P. H. C.; Oliveira, H. T. and Machado, E. C. (2003), Limnological study of Piraquara River (Upper Iguaçú river basin - Paraná, Brazil): Spatiotemporal variation of limnological variables and watershed spatial ordering. Braz. Arch. Biol. Technol., 46, 3, 383-394.

Parsons, T. R.; Maita, Y. and Lalli, C. M. (1984), A manual of chemical and biological methods for seawater analysis. Pergamon Press, Oxford.

Soares, C. R.; Angulo, R. J. and Lessa, G. C. (1997), Roteiro de excursão ao litoral do estado do Paraná. Morfodinâmica de ambientes atuais, evolução da planície durante o quaternário e problemas de erosão costeira. Congresso da Associação Brasileira de Estudos do Quaternário e Reunião sobre o Quaternário da América do Sul, Curitiba. UFPR, Curitiba, Paraná.

Strickland, J. L. H. and Parsons, T. R. (1972), A Practical Handbook of Sea-Water Analysis. Bull. 167. Alger Press.

Taniguchi, G. M.; Bicudo, D. C. and Sennab, P. A. C. (2004), Abiotic Variables in Littoral-Limnetic Gradient of an Oxbow Lake of Mogi-Guaçu River Floodplain, Southeastern, Brazil. Braz. Arch. Biol. Technol., 47, 961 - 971.

Thom, R. M.; Parkwell, T. L.; Niyogi, D. K. and Shreffler, D. K. (1994), Effects of graveling on the primary productivity, respiration and nutrient flux of two estuarine tidal flats. Mar. Biol., 118, 329-341.

Received: Janeiro 09, 2006; Revised: July 18, 2007; Accepted: December 05, 2008. 